\title{
The Commercial Date Industry in the United States and Mexico
}

\author{
Glenn C. Wright ${ }^{1}$ \\ School of Plant Sciences, University of Arizona, Yuma Agriculture Center, 6425 W. 8th Street, Yuma, AZ 85364
}

Additional index words. date palm, history, production

\begin{abstract}
The date palm (Phoenix dactylifera L.) originated in the Arabian Peninsula, spread throughout North Africa, then was carried to Mexico and the United States. Planting began in earnest in Arizona and California in the late 1800s and continues today. As of 2014, date production in Mexico and the United States is valued at almost $\$ 13,000,000$, and comprises about 7400 ha. 'Deglet Noor' and 'Medjool' are the major cultivars. Modern practices for date palm cultivation include planting, irrigation, fertilization, pollination, thinning the fruit, ringing the bunches, bagging the bunches, and harvest. After harvest, the fruit must be sorted, dried or rehydrated, and graded. Date palms are sometimes sold for landscaping purposes. Current research at the University of Arizona and University of California at Riverside is focused on pollination and thinning practices, improving fruit quality and controlling insects. There are four date palm germplasm collections located in Arizona and California.
\end{abstract}

\section{HISTORY, EXPANSION, AND LOCATION OF THE DATE PALM INDUSTRY}

Palms are of the class Monocotyledonae order Arecales and family Aricaceae. Among the genus Phoenix, there are 13 species of palms, which are native from the Canary Islands east across northern and central Africa, the extreme southeast of Europe (Crete), and southern Asia from Turkey east to southern China and Malaysia (Zaid, 2002). The name originates from the Phoenician word for date palm and the Greek word for finger-daktulos

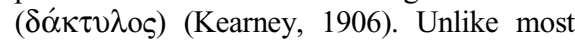
other fruit-bearing crops, dates are monocots, and they are dioecious. Dates have been an integral part of human history for thousands of years. It is difficult to determine the exact origin of date palm domestication because there is no wild ancestor (Terral et al., 2012). Domestication, in the oasis agroecosystem, likely occurred in Mesopotamia and perhaps also in North Africa (Danthine, 1937; Popenoe, 1913, 1973; Tengberg, 2012). Recent research suggests that date domestication originated from two major subpopulations: one centered around the Arabian (Persian) Gulf and Djibouti and the other in North Africa (Mathew et al., 2015; Zehdi-Azouzi et al., 2015) The Bible, the Koran, and the Torah mention date palms. There are examples of 2000-year-old glass perfume bottles blown in the form of a date (Phoenix Antiquities Art, 2016), Roman mosaics show date palms,

\footnotetext{
Received for publication 15 June 2016. Accepted for publication 26 Aug. 2016.

This paper was part of the colloquium "Alternative Specialty Crop: Opportunities and Challenges," presented at the 2015 ASHS Conference, New Orleans, LA, on 4 Aug. 2015, and sponsored by the Working Group of Asian Horticulture, Tropical Horticulture Working Group, and Pomology Working Group.

This is also a contribution of the Arizona Agricultural Experiment Station, University of Arizona, Tucson, AZ.

${ }^{1}$ Corresponding author. E-mail: gwright@ag.arizona. edu.
}

(Brooklyn Museum, 2015), and date palms appeared on the painted walls of Egyptian tombs and on Assyrian reliefs, perhaps as a symbol of fertility (Collins, 2006).

Greek and Phoenician traders brought date palms to Spain (Rivera et al., 2008), and Muslim conquerors brought additional date palms to Spain in the 8th century AD. During the rule of Abd al-Rahmān al-Dākhil (which started in $756 \mathrm{AD}$ ) "A date-palm tree, specially imported from Syria, was also planted to serve as a refreshing symbol of the great Arab civilization and culture" (Rauf, 2008). Spanish explorers and colonizers subsequently carried the palm to North and South America, including Chile and Peru and to areas that today fall in the Mexican states of Sonora, Sinaloa, and Baja California (Rivera et al., 2013). The tree produced well in these locations and exporters sent date fruit from Baja California, in the beginning of 1837 (Morton, 1987).

The Spaniards introduced dates to California and Arizona in the 17th and 18th centuries. The Jesuits established nine missions in Arizona from 1687 to 1781 , and they planted dates at the missions "wherever the climate was favorable for its growth" (Toumey, 1898). The Franciscans established additional missions in California, where, in 1769, the first date palm planting was made in San Diego (Butterfield, 1963; Trent and Seymour, 2010). Date plantings were not limited to California and Arizona. A famous date palm was associated with the house of Antonio de Sedella, also known as Pére Antoine, a Catholic priest and pastor of St. Louis Church in New Orleans beginning in the late 1770s. The palm may have been planted between 1811 and 1824 (Old New Orleans, 2015).

In the late $1850 \mathrm{~s}$, J.R. Wolfskill planted date seedlings at his farm, near Winters, CA (these palms still exist), and they were planted again in 1862 in the San Francisco Bay area (Nelson, 2009). Date seedlings were planted in Sonoma County in the early 1870 s (Klee, 1883), and date offshoots from Egypt, Algeria, and the Persian Gulf were planted at the University of California San Joaquin Valley Substation near Tulare, CA, in 1888 (Shinn, 1898). Lack of summer heat units in all these areas led to an inability of the fruit to mature, in some cases before killing frost arrived. This was also the case with dates planted at the Spanish Mission in San Diego. The first imported offshoots were planted in the Coachella Valley, near Indio, CA, in 1898. Fruit produced here was so superior that more northerly and westerly regions were never seriously considered for large-scale commercial date production again (Colley, 1973).

The USDA began importing offshoots from the Middle East and North Africa in the 1880s (Nixon, 1950). Workers removed offshoots from the mother plant and camel caravans transported them to a railhead for further transport to a seaport or directly to the seaport. Offshoots were then packed in wet sawdust and placed in wooden crates so as to survive the long voyage to Los Angeles or San Francisco. The USDA and the University of Arizona personnel coordinated importation and distribution. In 1890, ten palms, from Algeria, Egypt, and Arabia were planted in Phoenix, and one died. Six were females and three were males. Additional palms from this shipment were sent to Las Cruces, NM; Yuma, AZ; National City, Pomona, Tulare; and Indio, CA (Toumey, 1898). Thirteen additional palms were sent to Yuma, but all were killed by a flood in 1891. Major imports of offshoots by the USDA continued until 1908 (Hilgeman, 1972).

There were also several private importation programs (Simon, 1978). Mr. Bernard Johnson brought in 129 offshoots from Algeria in 1903 and 3000 offshoots in 1912. In 1913, 15,000 offshoots were imported by West India Gardens. Private individuals imported thousands more date palm offshoots through 1922. The most promising imported cultivars from those planted in 1902 were 'Braim', 'Barhi', 'Khadrawy', 'Kustawy', 'Nesheem', 'Nazel el Bacha', 'Maktoom Hayany', 'Zahidi', and 'Deglet Noor'. Local cultivars were also developed (Hilgeman, 1972).

By 1934, there were over 500 acres of dates in Arizona, mostly in Phoenix. Arizona hectarage peaked in the 1940s. California hectarage peaked at over 5000 acres during the $1970 \mathrm{~s}$, and then acreage plateaued until recently. By 1945, the California date crop 
amounted to about 9000 MT (Butterfield, 1963). Almost every grower built his own packing shed and developed his own sales program. In many cases, the growers' wives and families played a prominent part in curing, packing, and selling the fruit. The most successful programs relied on direct sales to the consumer by mail order or local retail sales (Wright, 2012). Marketers portrayed date fruit as exotic due to its place of origin. Images of camels, women in Arabic dress, and buildings of Arabian style were prominently included in date fruit advertisements. Even today, the National Date Festival in Indio, CA, has a camel race (Press-Enterprise, 2015).

The commercial date industry in the United States and Mexico exists today in California, Arizona, and the Mexican states of Sonora, Baja California, Baja California Sur, and Coahuila (Fig. 1). 'Deglet Noor' and 'Medjool' are the two cultivars that predominate. Producers in Arizona and California also grow other cultivars such as 'Barhi' (in the khalal, rutab and tamar stage), 'Black Sphinx', 'Dayri Halawi', 'Honey', 'Khadrawy', 'Thoory', and 'Zahidi'. All are grown for the local, specialty and farmers market trade.

Within California, as of 2014, there were 3426 ha of date palms in Riverside County, primarily in the Coachella Valley and the Palo Verde Valley (Riverside County Agricultural Commissioner, 2014), 869 ha in Imperial County, made up of the Imperial Valley and the Bard Valley (Imperial County Agricultural Commissioner, 2014), and just 25 ha in Inyo County (Joel, 2013). Within Inyo County, a few hundred 'Deglet Noor' trees planted in the mid-1920s grow at Furnace Creek, in the middle of Death Valley National Park. These trees are no longer commercially farmed. Commercial production of 'Deglet Noor', 'Dayri', 'Halawy', 'Honey', 'Khadrawy', and 'Medjool' is found at the China Ranch, near Tecopa, CA (Johnson et al., 2016).

About 1396 ha of dates were growing in Arizona in 2014, chiefly in the Yuma area and the Hyder Valley. Sonora had 907 ha of dates growing in 2014, all near San Luis Rio Colorado, followed by 444 ha in Baja California, all near Mexicali (Sagarpa, 2014). There are 345 ha in Baja California Sur and 15 ha in Coahuila (Sagarpa, 2014). Most date orchards in Coahuila and Baja California Sur are in traditional oases, and are not intensively farmed.

Date production varies from 3.52 to 7.21 MT. $\mathrm{ha}^{-1}$ in the United States and from 0.18 to 6.99 MT.ha' ${ }^{-1}$ in Mexico (Table 1). 'Deglet Noor' typically yields more than 'Medjool'. Additionally, 'Medjool' fruits are thinned, further reducing the yield. Thus, production is greater in areas where there are more mature trees, and where 'Deglet Noor' is the predominate cultivar. In contrast, production is less where the majority of the trees are immature and where there are more 'Medjool' trees planted. The value of production is about USD \$71 million for California and about USD \$35 million for Arizona. Total Mexican production is valued at about USD \$12.8 million. While dates grown in Sonora and Baja California are farmed commercially, most dates growing in Baja California Sur are found in the traditional oases, and are not farmed intensively (de Grenade, 2013). Hence, production values are less in Baja California Sur.

\section{MEDJOOL AND DEGLET NOOR, THE LEADING CULTIVARS}

Although the 'Deglet Noor' was just one of many cultivars to be imported to the United States in the beginning of the 20th century, growers soon recognized it as a valuable cultivar (Hodel and Johnson, 2007). Originally from Algeria, 'Deglet Noor' annual yields can surpass $300 \mathrm{lbs}$ per palm per tree. The fruit is firm, and the flavor is subtly sweet and nutty. Rain and humidity damage fruit quality, therefore the cultivar is more suited for areas that experience dry weather in late summer and fall, such as the Coachella Valley, rather than areas, such as Arizona, that are more significantly affected by the late-summer Southwest monsoon. The 'Deglet Noor' appeals to those consumers who prefer a date that is slightly less sweet and more firm. 'Deglet Noor' is sometimes sold pitted or chopped, and is used for baking and processing into paste. A 100-g serving of 'Deglet Noor' date contains 282 calories, $14 \%$ of the daily value of potassium and $32 \%$ of the daily value of the fiber needed by a healthy adult (Nutrition Value, 2016a).

The final major date cultivar to be imported into the United States was the 'Medjool'. This date comes from southeastern Morocco. During the 17th Century it was known as a high-quality date and fruit sold at a higher price than other cultivars in the markets of England and Spain (Swingle, 1945). W.T. Swingle imported the first 'Medjool' offshoots

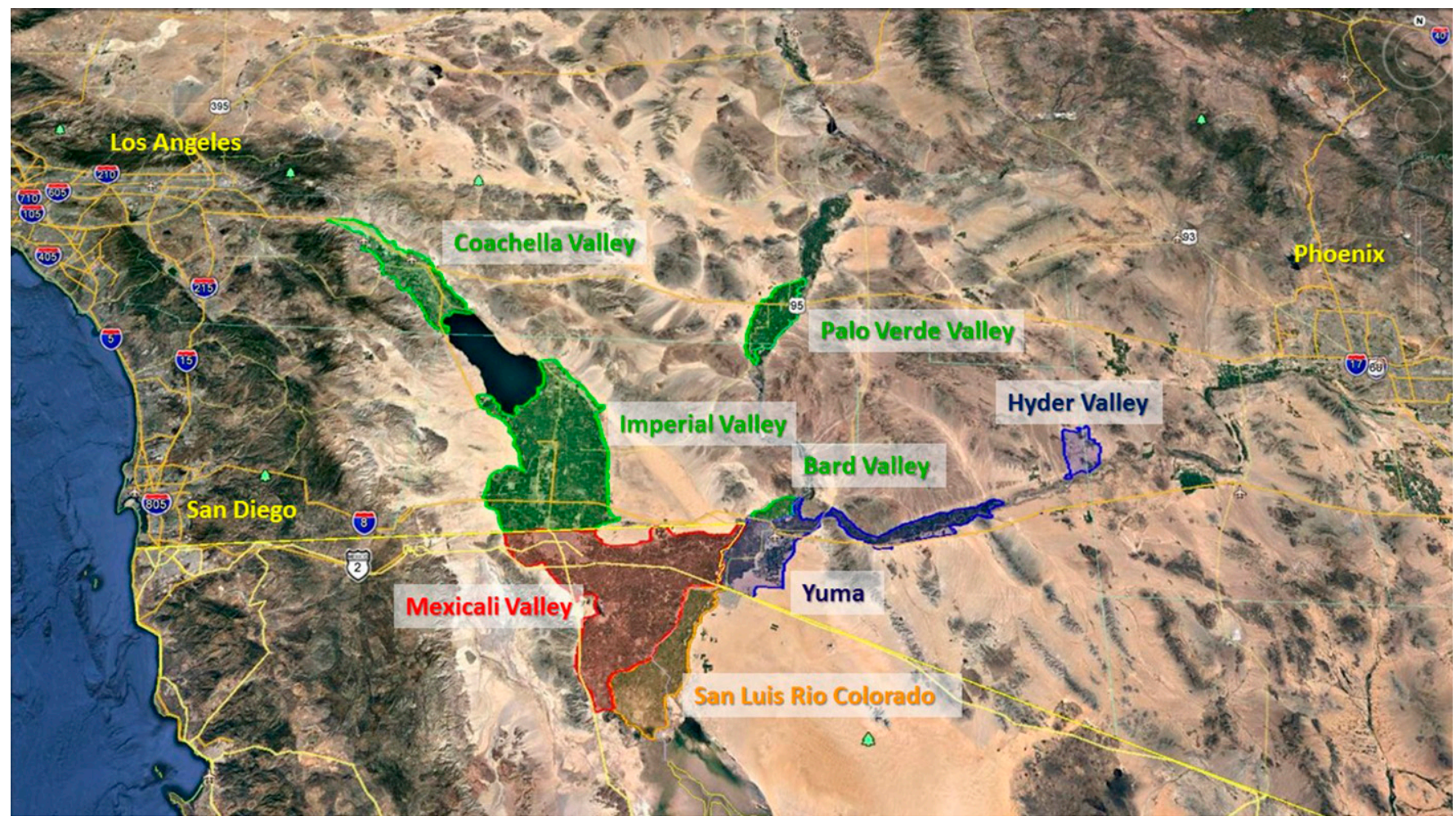

Fig. 1. Major date growing areas in the United States and Mexico. Areas within California are shown in green, within Arizona in blue, within Sonora in orange, and within Baja California in red. Minor areas within Inyo County, CA, Baja California Sur, and Coahuila are not shown. 
Table 1. U.S. and Mexican commercial date production and value for 2014

\begin{tabular}{|c|c|c|c|c|}
\hline Country & State & County & Production (MT $\left.\cdot \mathrm{ha}^{-1}\right)$ & $\begin{array}{l}\text { Value of production } \\
\qquad(\$ \times 1,000)\end{array}$ \\
\hline \multirow[t]{4}{*}{ United States } & California $^{z}$ & Riverside & 5.94 & 36,031 \\
\hline & & Imperial & 7.21 & 35,612 \\
\hline & Arizona (estimated) ${ }^{\mathrm{y}}$ & Yuma & 3.52 & 35,375 \\
\hline & & Total & & 107,018 \\
\hline \multirow[t]{5}{*}{$\operatorname{Mexico}^{x}$} & Sonora & & 6.99 & 8,019 \\
\hline & Baja California & & 6.07 & 4,650 \\
\hline & Baja California Sur & & 0.18 & 145 \\
\hline & Coahuila & & 2.31 & 26 \\
\hline & & Total & & 12,840 \\
\hline
\end{tabular}

${ }^{\mathrm{z}}$ California data from Riverside County Agricultural Commissioner (2014) and Imperial County Agricultural Commissioner (2014). Data not available for Inyo County.

${ }^{y}$ Arizona data estimated from information provided by personal contacts of the author.

${ }^{\mathrm{x}}$ Mexico data from Sagarpa (2014).

to the United States in 1912, but it is unknown what happened to them. An additional importation was made in 1927. In this case, Swingle imported six large and five small offshoots from Boudnib, Morocco. Bayoud disease (Fusarium oxysporum) was killing many of the trees in Morocco (and it still is), and so the palms were quarantined in a state with no palms in it. Nevada was an obvious choice. USDA personnel found a Native American farmer in southern Nevada to care for the offshoots, but he had no title to his land, so the Indian reservation was enlarged to encompass his farm (Thackery, 1952). Nine of the 11 offshoots survived, and were moved to USDA research station at Indio in 1934. Subsequent propagations increased the numbers of 'Medjool' offshoots, and Mr. Stanley Dillman of Bard, CA took 24 offshoots from the original 9 surviving 'Medjool' trees and planted them in the Bard Valley in 1944 (Dillman, 1945). There are six that remain. Today, $99 \%$ of the dates grown in Yuma and the Bard Valley are 'Medjool' (Wright, 2012).

Many consumers prefer the 'Medjool' date because of its large size; it can be three times the size of a 'Deglet Noor'. 'Medjools' are sweeter than most other cultivars, with a maple syrup-like flavor. When commercially harvested and processed, they are moist and soft, but not so soft that they will be damaged while being packed. The highest quality 'Medjool' dates have $22 \%$ to $25 \%$ moisture content. Most 'Medjool' fruit are eaten fresh. The cultivar also can produce more than $200 \mathrm{lbs}$ of fruit per palm when mature, and will produce many offshoots. A 100 -g serving of 'Medjool' date contains 277 calories and $15 \%$ of the percent daily value of potassium and $27 \%$ of the fiber needed by a healthy adult (Nutrition Value, 2016b).

\section{GROWING DATES}

Date palms are said to live with "their feet in water and their heads in the fire (Mitchell, 1921)," which means they must have adequate water, yet thrive in arid areas with enough heat to produce fruit. Therefore, date palms production is found in hot, dry desert climates of the world. Without sufficient heat, the palm is unable to mature the crop before winter. Early-ripening varieties of dates require at least 2000 heat units to ripen the fruit, while late-ripening varieties, such as 'Deglet Noor' require at least 2750 h (Burt, 2008). Also, too much humidity and rain during harvest leads to fermentation and loss of fruit quality.

In the Eastern Hemisphere, dates are mainly grown in the area ranging from western India and Pakistan on the east, across the Arabian Peninsula and throughout North Africa (Zaid, 2002). The majority of palms grown in these regions are found in the oases, where the date palm is the dominant tree. In the oasis, the palm provides shade and some of the economic livelihood of villages and farms, including fruit as well as leaves and trunks for fencing, roofing, and support beams for buildings. Palm fronds can also be made into baskets (Potts, 2002). Other fruit trees, vegetables, and row crops grow underneath the dominant palm, and small canals distribute water to the fields where flood irrigation is practiced (Tengberg, 2012). Palms outcross, so there are numerous local cultivars. In the oasis, palm seeds are distributed haphazardly by birds and animals, and palm offshoots may not be removed from the mother plant, leading to groupings of plants. Newer plantings of date palms in these areas are often planted away from the oases, in a conventional manner, with fewer cultivars and consistent row and tree spacing. These new orchards are often established with pressurized irrigation systems.

In the United States and Mexico, modern practices for date palm cultivation include planting, irrigation, fertilization, dethorning the fronds, pollination, thinning the fruit, ringing the bunches, bagging the bunches, and harvest (Nixon and Carpenter, 1978; Paulsen, 2005; Tate and Hilgeman, 1956).

Dates may be propagated by seed, offshoot, or via tissue culture. Seeds are not a viable option because dates outcross easily and therefore the seedlings are not true to type (Toumey, 1898). Additionally, without using DNA analysis (Al-Mahmoud et al., 2012), it is not known if seeds are male or female until they bear fruit. Many of the date palms produced worldwide are derived from tissue culture because there is a large demand for planting material, a shortage of offshoots, and the threat of disease if offshoots are used. The opposite is true in the United States and in Mexico. Growers have collected offshoots from their trees for many years, and they are usually planted to increase the orchard size, sometimes sold, but seldom given away or destroyed.

Offshoots are suitable for collection from the mother palms when they are about 1 to $1.3 \mathrm{~m}$ tall, weighing 20 to $50 \mathrm{~kg}$ and with a diameter of 20 to $35 \mathrm{~cm}$ (Nixon and Carpenter, 1978). They are removed in the late spring or early summer when warm soil temperatures promote root growth (Aslan et al., 1991). A team of workers remove offshoots from the mother plant using a chisel and a sledgehammer to cut the connection between the two. Offshoots are then planted directly into their new location in the orchard or are planted into nursery pots. Leaves of the newly cut offshoot are wrapped in burlap to reduce moisture loss, but these leaves will eventually die. Up to 9 months may pass before new leaf growth from the center of the palm indicates that the palm has survived the planting operation. Offshoots in pots remain there for 1 year before placement in the field. Survival rate following transplanting from pots or direct planting ranges from $50 \%$ to $100 \%$. Survival of potted offshoots and tissue culture plants can approach $100 \%$, whereas offshoots planted directly in the field will have a lower survival rate (Al-Ghamdi, 1988; Aslan et al., 1991). When removed from the mother palm, offshoots with roots are more likely to survive than those that have no roots. Tissue culture plants have a very high survival rate because they have well-developed root systems upon planting. Trees are usually planted from 9 to $10 \mathrm{~m}$ apart in a square configuration. For 'Medjools', there are 49 female palms planted for every one male palm (Paulsen, 2005). Male palms are propagated as offshoots or through tissue culture from other males, but all males originally came from seed propagation. In areas such as Arizona, where 'Medjool' is predominant, there is little outcrossing so that seedling male palms and their subsequent offshoots are likely to be 'Medjool', but where there is a mixture of cultivars, male seedlings and offshoots may be hybrids.

Offshoots and tissue culture plants are anticipated to have harvestable yield after about 5 years. Date palm yield increases greatly from 1 year to the next for the next 8 to 10 years. Yield then increases slowly beginning at age 12 to 15 years. In general, date palms have been known to be productive up to 150 years; however, yields diminish after 50 years (Chao and Krueger, 2007).

Despite their adaptability to the desert, date palms require significant quantities of water. Nixon and Carpenter (1978) recommended about 2.7 to $3.6 \mathrm{~m}$ of water annually for date palms growing in sandy soils under flood or furrow irrigation. Mature 'Deglet Noor' palms grown on heavier soil required more than $1.8 \mathrm{~m}$ of water for adequate growth and production and to avoid salt accumulation (Furr and Armstrong, 1958). More recent calculations based on evapotranspiration suggest that date palms on heavier soils require 
about $2.1 \mathrm{~m}$ of water per year, or an average of $23.66 \mathrm{~m}^{3}$ per day. In Arizona, California, and Mexico, there are established irrigation districts that control delivery of water from the Colorado River to the farms through canals. Within many districts, established palms are flood irrigated; however, there is increasing use of microsprinkler irrigation. Outside the districts, growers irrigate their date palms with well water drawn from aquifers. In these cases, pressurized irrigation systems are used to deliver water. Most systems employ fan-jet spray emitters or drip emitters to deliver sufficient quantities of water to the trees. Palms that lack sufficient water will be smaller, and have fewer fruiting arms, with smaller fruit (Aldrich, 1942).

Some growers in the region use conventional fertilization in their orchards, while others choose to use organic fertilization practices (Paulsen, 2005). For the conventional orchards, most growers make applications of $\mathrm{N}, \mathrm{P}, \mathrm{K}, \mathrm{Ca}, \mathrm{Mg}, \mathrm{Zn}$, and $\mathrm{B}$. All of these elements are broadcast on the soil, or applied through the irrigation system, except for $\mathrm{P}$ which is typically applied as a band along the planting row. Organic matter is also applied, typically in the form of composted cow or chicken manure (Aslan et al., 1991). Organic producers typically apply only the manure. In the case of flood irrigated orchards, fertilizer is applied three to five times a year, while plantings irrigated with drip or fan-jet emitters can have sporadic or continuous application.

Workers remove thorns from the fronds in late winter or early spring (Tate and Hilgeman, 1956), using a long-handled knife. This is done to improve worker safety around the palm.

Pollination is the next major operation of the season, and it usually begins in late February when the male palm flowers begin to emerge (Nixon and Carpenter, 1978). Workers collect the male spathes, and open them to reveal the male flowers. The male flowers are removed from the spathe and hung or laid to dry in a room with constant air flow until the flowers dehisce, releasing the pollen (Paulsen, 2005). Workers shake the male flowers, or the flowers are tumbled in rotating barrels, then the workers collect the pollen in containers and store it under refrigeration or frozen until needed.

The female flowers appear in late February or early March. Workers apply pollen to the flowers using squeeze bottles or handheld or tractor-pulled mechanical blowers that blow the pollen through the air until it comes in contact with the sticky stigmas of the female flowers (Nixon and Carpenter, 1978). Pollen is sometimes mixed, or "cut" with corn starch or talc so that there is sufficient pollen to pollinate all the flowers. Since female flowers emerge gradually, they must be pollinated multiple times. Trees are typically pollinated once a week for 4 to 6 weeks.

Following pollination, the developing 'Medjool' fruitlets are thinned (Zaid, 2002). Thinning increases fruit size and allows air movement through the bunches, which reduces the potential for fermentation when the dates are mature. 'Deglet Noor' fruit are not thinned, because fruit size is not as important with this cultivar. However, the center portion of the inflorescence is removed which increases fruit size and facilitates bunch management (Chao and Krueger, 2007; Nixon and Carpenter, 1978). Workers thin the 'Medjool' fruits by hand and about $70 \%$ of the fruit are removed. Date growers attempt to thin fruit when they are small, generally about 7.5 to $10 \mathrm{~mm}$ in diameter. First, the center portion of the inflorescence (the bunch) is removed completely, and then additional rachillae (strands) are removed until 35 to 45 remain. Fruit are thinned from the remaining strands until from 12 to 20 remain per strand. Two single date fruits grow opposite each other on the strand, but sometimes two date fruits grow side by side (these are known as "doubles"). In the thinning process, fruit growing opposite each other are thinned to a single fruit per position, and any doubles are thinned to a single fruit. Thinning is the costliest cultural practice that occurs before harvest. Also at this time, workers train the 'Medjool' bunches by tying them with twine to upper branches for support which will be needed as the fruit get heavier. At the same time, the workers also gently bend the bunches downward by tying them to lower branches so that the fruit hangs below the fronds. This will make harvest easier (Paulsen, 2005).

In July, the fruit is no longer green, but has reached the khalal stage (Nixon and Carpenter, 1978). At this stage, the 'Deglet Noor' and 'Medjool' fruit is yellow (other varieties can be red) and has attained its ultimate size, and spreader rings and bags are placed on the 'Medjool' bunch. Spreader rings are made of galvanized wire, and are inserted into the 'Medjool' bunch from the bottom (Dillman, 1945). They serve to spread the strands, improve air circulation, and reduce the chance of subsequent fermentation that occurs when the fruit begin to turn brown and soften. Workers then cover the fruit bunches with bags, beginning in July (Paulsen, 2005). The white or black bags are made of cotton and/or synthetic fabrics. Color and mesh size affect ripening time and moisture retention within the bunch. The bags also protect the fruit from rain and bird predations, and, once tied shut, catch any fruit that falls from the bunch before harvest. 'Medjool' fruit ripens during the late summer when rain can lead to significant fermentation, incidence of disease and loss in quality.

Workers cover 'Deglet Noor' bunches with bags made of craft paper, which provide the bunch with protection against the rain and against bird predation (Nixon and Carpenter, 1978). Occasionally, fabric bags are used in 'Deglet Noor' dates to reduce the incidence of carob moth and Bank's Grass mite infestations. No spreader rings are inserted into the bunches of 'Deglet Noor' fruit. 'Deglet Noor' ripens in midautumn when rainfall is not as common; therefore, bunch rots and fruit fermentation is less common and air circulation in the bunch is not as critical.

'Medjool' ripens early (Hodel and Johnson, 2007). Harvest begins in mid-to-late August once some of the fruit have reached the rutab stage. At this stage, the fruit begin to soften and turn brown, progressing from the tip to the calyx. Fruit in a bunch does not ripen simultaneously; some may be mostly in the khalal stage, others may be mostly in the rutab stage, and others may be in the fully dried tamar stage. Only the fruit that is at least partially rutab is harvested. Therefore, workers must return to each bunch about every 10 to $14 \mathrm{~d}$ to harvest fruit (Paulsen, 2005). Harvest continues for about 6 weeks, until all the fruit on the bunch are rutab or tamar. Smaller palms are harvested from the ground or from ladders, but larger palms are harvested using forklifts or reachlifts. Growers have built harvest platforms that are attached to the lifts, and can lift up to eight workers up to the crown of the tree (R. Hill, personal communication). Workers use harnesses attached by cables to the platform for safety. Once in the crown, workers untie the bags, shake the bunches and some of the rutab or tamar fruit will fall into a tray placed below the bag. Workers than retie the bags and lower the trays to the ground using ropes and hooks, or store the trays on the harvest platforms until the platform is lowered to the ground. Unmarketable dates are left in the field, and then trays of dates are then stacked on trailers and taken to the packinghouse. Some growers have developed harvest aids that speed transfer of the dates from the platform to the harvest trailer and speed field sorting.

'Deglet Noor' ripens late (Hodel and Johnson, 2007); harvest begins in the fall, generally in October. While some growers use the platforms as described above, others have mounted ladders on the trees to facilitate access. Once most of the fruit are in the rutab or tamar stage, workers climb or are lifted to the crown, where they cut the entire bunch and lower it to the ground using hooks and ropes. Dates from the bunch are shaken into a bin which is then taken to the packinghouse.

Since the maturity of the date fruit is variable once harvested, most of these must be dehydrated or "dried" to an optimal moisture content of $22 \%$ to $25 \%$ (Zaid, 2002) and uniform color. Dates must be sorted by color before drying so that all the dates will be uniformly dehydrated. Some growers still practice traditional sun drying, where trays of color-sorted dates are placed on concrete pads and exposed to direct sunlight for 2 to $5 \mathrm{~d}$. This practice is more common in Mexico than in the United States. Other growers choose to use forced-air drying rooms, where the fruit are exposed to 50 to $55^{\circ} \mathrm{C}$ air for 24 to $72 \mathrm{~h}$ (Zaid, 2002). A few dates are too dry upon harvest, and must be rehydrated (Nixon and Carpenter, 1978) using 60 to $65^{\circ} \mathrm{C}$ steam for 4 to $8 \mathrm{~h}$. Dates are then cleaned and sorted according to grade. Most small packinghouses grade the fruit by hand, but the larger ones have developed 
electronic sorters. Grade standards are generally uniform for each of the two cultivars. Following grading, date fruit are packed into the traditional 5-kg box, into various consumer packs, chopped and packaged, or processed for date paste. Chopped dates or processed date paste are found in baked goods, value-added products such as "date rolls," and in energy bars.

Occasionally, the date palm is not valued for its fruit, but instead for its usefulness as a landscape specimen tree (Hodel and Johnson, 2007). Before the economic downturn of 2008, many date palms were planted in the landscape of new subdivisions, shopping malls, commercial buildings, or alongside roads or in medians. Older palms, particularly the 'Deglet Noor' or 'Zahidi' cultivars, were uprooted because they were too tall to harvest for fruit, because the fruit was of too little value, or because the orchard was sold for other commercial purposes. Cost to the buyer could exceed $\$ 300$ per meter of trunk height. To remove a palm, workers excavate around the root ball, and then push over the tree using a backhoe. About $50 \%$ of the fronds are removed, the remaining fronds are tied, then the palms are lifted onto a semitrailer truck, the root ball is wrapped in plastic to slow water loss, the palm is secured and transported to a new destination. Mature palms are frequently removed from date gardens in California and Arizona and planted Florida, Louisiana, and Nevada. Most landscape plantings of date palms are in areas not conducive to their culture and growth and are not maintained properly. Since 2008, the trade in date palms for landscaping has slowed considerably, but it continues, and has increased as the economy improves.

Current date palm research occurs at the University of Arizona, the University of California at Riverside, and the USDA. Researchers at the University of Arizona are working on developing leaf nutrient standards for date palms. We are also researching pollination and thinning methodologies that will reduce the cost of fruit thinning, and we are working to reduce skin separation in 'Medjool' dates. At the University of California, Riverside, researchers are working on controlling pests such as carob moth, Ectomyelois ceratoniae (Zeller) in 'Deglet Noor' and Banks grass mite, Oligonychus pratensis (Banks), and biological control of the Pink Hibiscus Mealybug [Maconellicoccus hirsutus (Green)] in date palm (Negm et al., 2015; Perring et al., 2015). Date palm germplasm collections in Arizona are maintained at the University of Arizona in Yuma (15 cultivars) and at Arizona State University in Tempe (32 cultivars). In California, the USDA collection is at the University of California, Riverside, Coachella Valley Agricultural Research Station in Thermal, CA (118 accessions, including 37 cultivars). There is also a private laboratory that is developing superior tissue culture methodologies for many of the cultivars in the USDA collection, especially those that no longer produce offshoots and cannot be propagated asexually (Phoenix Agrotech, 2016).

\section{Literature Cited}

Aldrich, W.W. 1942. Some effects of soil moisture deficiency upon Deglet Noor fruit. Report of the Date Growers Institute 19:7-10.

Al-Ghamdi, A.S. 1988. Rooting of date palm offshoots as affected by offshoot size, cultivar, and indole butyric acid injection. Acta Hort. 226:379-388

Al-Mahmoud, M.E., E.K. Al-Dous, E.K. AlAzwani, and J.A. Malek. 2012. DNA-based assays to distinguish date palm (Arecaceae) gender. Amer. J. Bot. 99:7-10.

Aslan, S., R. Neja, D. Estrada, W. Dignon, and S. Mitchell. 1991. Soil, water and climactic considerations in selecting date palm planting sites in the Coachella Valley. Coachella Valley Water Conservation District, Coachella Valley Water District and Riverside County Farm Bureau Publication.

Brooklyn Museum. 2015. Mosaic of date palm tree. 13 June 2016. <https://www.brooklynmuseum org/opencollection/objects/17086/Mosaic_of_ Date_Palm_Tree $>$.

Burt, J. 2008. Growing date palms in Western Australia. Government of Western Australia Dept. of Agr. and Food Farmnote No. 55/99. 20 Aug. 2016 $<$ http://citeseerx.ist.psu.edu/viewdoc/download? doi $=10.1 .1 .565 .4832 \&$ rep $=$ rep1\&type $=$ pdf $>$

Butterfield, H.M. 1963. A history of subtropical fruits and nuts in California, University of California. 18 Aug. 2016. <http://websites.lib.ucr.edu/agnic/ butterfield/butterfield.pdf $>$.

Chao, T.C. and R.R. Krueger. 2007. The Date Palm (Phoenix dactylifera L.): Overview of biology, uses, and cultivation. HortScience 42:1077-1082.

Colley, C.C. 1973. First commercial date palm experimentation in California, 1882-1900. South. Calif. Q. 55:253-260.

Collins, P. 2006. Trees and gender in Assyrian art. Iraq 68:99-107.

Danthine, H. 1937. Le palmier-dattier et les arbres sacrés dans l'iconographie de l'Asie Occidentale ancienne. Librairie Paul Geuthner, Paris.

de Grenade, R. 2013. Date palm as a keystone species in Baja California peninsula, Mexico oases. J. Arid Environ. 94:59-67.

Dillman, S. 1945. Date management practices at Bard, California. Report of the Date Grower's Institute 22:16-17.

Furr, J.R. and W.W. Armstrong, Jr. 1958. The influence of heavy irrigation and fertilization on growth, yield and fruit quality of 'Deglet Noor' dates. Report of the Date Grower's Institute 35:22-24.

Hilgeman, R.H. 1972. History of date culture and research in Arizona. Report of the Date Grower's Institute 49:11-14.

Hodel, D.R. and D.V. Johnson. 2007. Dates: Imported and American cultivars of dates in the United States. University California, Agriculture and Natural Resources Publicaton No 3498. ANR Communications Services, Oakland, CA.

Imperial County Agricultural Commissioner. 2014 2014 Imperial county crop and livestock report. Imperial County Agriculture Commissioner's Office, El Centro, CA. 13 June 2016. <http:// www.co.imperial.ca.us/ag/crop_\&_livestock reports $/ 2014 \% 20$ Crop $\% 20$ and $\% 20$ Livestock $\% 20$ Report.pdf>.

Joel, S. 2013. Cool oasis: A date at Death Valley's China Ranch. Zester Daily, Los Angeles, CA. 13 June 2016. <http://zesterdaily.com/world/cooloasis-a-date-at-death-valleys-china-ranch/>.

Johnson, D.V., J.C. MacKnight, and S. Zona. 2016. Date palms of Furnace Creek Ranch and China Ranch in Inyo County, California. Fruit Gardener 48:6-15.
Kearney, T. 1906. Date cultivars and date culture in Tunis. U.S.D.A. Bureau of Plant Industry No. 92.

Klee, W.G. 1883. Culture of the date. US Department of Agriculture Rpt. No. 24. US Government Printing Office, Washington, DC.

Mathew, L.S., M.A. Seidel, B. George, S. Mathew, M. Spannagl, G. Haberer, M.F. Torres, E.K. AlDous, E.K. Al-Azwani, I. Diboun, R.R Krueger, K.F.X. Mayer, Y.A. Mohamoud, K. Suhre, and J.A. Malek. 2015. A genome-wide survey of date palm cultivars supports two major subpopulations in Phoenix dactylifera. G3 (Bethesda) 5(7):1429-1438.

Mitchell, G.E. 1921. Americanizing the Arabian date. Travel 37(2):17-20, 46

Morton, J.F. 1987. Fruits of warm climates. J.F.M Press, Miami, FL.

Negm, M.W., G.J. De Moraes, and T.M. Perring. 2015. Mite pests of date palms, p. 347-389. In: W. Waqas, J. Romeno Faleiro, and T.A. Miller (eds.). Sustainable pest management in date palm: Current status and emerging challenges. Springer Intl. Pub., Cham, Switzerland.

Nelson, D. 2009. History lessons. The Leaflet: A semiannual newsletter from the UC Davis Department of Plant Sciences. Davis, CA 7:16-21.

Nixon, R.W. 1950. Commercial and imported cultivars of dates in the United States. USDA Circular No. 834. US Government printing office, Washington, DC.

Nixon, R.W. and J.B. Carpenter. 1978. Growing dates in the United States. USDA Agr. Information Bull. 207. US Government Printing Office, Washington, DC.

Nutrition Value. 2016a. Deglet Noor date nutrition value. Nutritionvalue.org. 12 June 2016. <http:// www.nutritionvalue.org/Dates\%2C_deglet_noor_ nutritional_value.html $>$.

Nutrition Value. 2016b. Medjool date nutrition value. Nutritionvalue.org. 12 June 2016. $<$ http://www.nutritionvalue.org/Dates\%2C medjool_nutritional_value.html $>$.

Old New Orleans. 2015. Pere Antoine's date palm. Old New Orleans, New Orleans, LA. 11 June 2016. <http://old-new-orleans.com/NO_Pere Antoine.html>

Paulsen, M.E. 2005. The amazing story of the fabulous Medjool date. Marc Paulsen Press, Tualatin, OR.

Perring, T.M., A. Hamadttu, F. El-Shafie, and W. Wakil. 2015. Carob Moth, Lesser Date Moth, and Raisin Moth, p. 109-167. In: W. Waqas, J. Romeno Faleiro, and T.A. Miller (eds.). Sustainable pest management in date palm: Current status and emerging challenges. Springer Intl. Pub., Cham, Switzerland.

Phoenix Agrotech. 2016. Date palm varieties. Phoenix Agrotech, Santa Ana, CA. <http:// phoenixagrotech.com/desert-agriculture/datepalms/date-palm-varieties/>.

Phoenix Antiquities Art. 2016. Roman glass perfume bottle in the shape of a date. E-tiquities by Phoenix Ancient Art. Geneva, Switzerland. 13 June 2016. <http://www.e-tiquities.com/RomanGlass-Perfume-Flask-in-the-Shape-of-a-DateAmber-Roman>

Popenoe, P.B. 1913. Date growing in the old world and the new. George Rice and Sons, Los Angeles, CA.

Popenoe, P.B. 1973. The date palm. In: H. Field (ed.). Field research projects. Coconut Grove, Miami, FL.

Potts, D. 2002. Feast of dates. Trident Press, Ltd., London, UK.

Press-Enterprise. 2015. Indio: 5 things to see at the date fest. The Press Enterprise Newspaper, Riverside, CA. 14 June 2016. <http://www.pe. com/articles/date-760039-fair-walking.html>. 
Rauf, A. 2008. Muslim rule in Spain. Renaissance: A monthly Islamic journal. 18 Aug. 2016. <http:// www.monthly-renaissance.com/issue/content. aspx?id=471>.

Rivera, D., D. Johnson, J. Delgadillo, M.H. Carrillo, C. Obón, R. Krueger, F. Alcaraz, S. Rios, and E. Carreño. 2013. Historical evidence of the Spanish introduction of date palm (Phoenix dactylifera L., Arecaceae) into the Americas. Genet. Resources Crop Evol. 60:1433-1452.

Rivera, D., C. Obón de Castro, E. Carreño, C. Inocencio, F. Alcaraz, S. Ríos, J.A. Palazón, L. Vázquez, and E. Laguna. 2008. Morphological Systematics of date palm diversity (Phoenix, Arecaceae) in Western Europe and some preliminary molecular results. Acta Hort. 799:97-104.

Riverside County Agricultural Commissioner. 2014. Riverside county agricultural production report 2014. Riverside County Agricultural Commissioner's Office, Riverside, CA. 13 June 2016. <http://www.rivcoag.org/Portals/ 0/Publications/Crop\%20Reports-EntireCounty/ 2014\%20Riverside\%20County\%20Agricultural $\% 20$ Production\%20Report.pdf $>$.

Sagarpa. 2014. Cierre de la producción agrícola por estado. Secretaría de Agricultura, Ganadería,
Desarrollo Rural, Pesca y Alimentación. México City. 12 June 2016. <http://infosiap.siap.gob. $\mathrm{mx} /$ aagricola_siap_gb/icultivo/index.jsp $>$.

Shinn, C.H. 1898. San Joaquin Valley Culture Substation, A partial report of work of the agricultural experiment stations of the University of California for the years 1895-96. Univ. Calif. Press, Berkeley.

Simon, H. 1978. The date palm: Bread of the desert. Dodd, Mead and Co., New York, NY.

Swingle, W.T. 1945. Introduction of the Medjool date from Africa into the United States. Report of the Date Grower's Institute 22:15-16.

Tate, H.F. and R.H. Hilgeman. 1956. Dates in Arizona. Arizona Agricultural Experiment Station Bulletin A-22, Tucson, AZ.

Tengberg, M. 2012. Beginnings and early history of date palm garden cultivation in the Middle East. J. Arid Environ. 86:139-147.

Terral, J.-F., C. Newton, S. Ivorra, M. GrosBalthazard, C.T. de Morais, S. Picq, M. Tengberg, and J.C. Pintaud. 2012. Insights into the historical biogeography of the date palm (Phoenix dactylifera L.) using geometric morphometry of modern and ancient seeds. J. Biogeogr. 39:929-941.
Thackery, F.A. 1952. A few notes on the 'Medjool' date during its isolation in Nevada. Report of the Date Grower's Institute 29:8-10.

Toumey, J.W. 1898. The date palm. Ariz. Agr. Exp. Sta. Bull. 29.

Trent, H. and J. Seymour. 2010. Examining California's first palm tree: The Serra palm. J. San Diego Hist. 56:105-120.

Wright, G.C. 2012. Date cultivation in Arizona and the Bard Valley. J. Amer. Pom. Soc. 66:110-117.

Zaid, A. 2002. Date palm cultivation. FAO Plant production and protection paper No. 156. Food and Agriculture Organization of the United Nations, Rome, Italy.

Zehdi-Azouzi, S., E. Cherif, S. Moussouni, M. Gros-Balthazard, S. Abbas Naqvi, B. Ludeña, K. Castillo, N. Chabrillange, N. Bouguedoura, M. Bennaceur, F. Si-Dehbi, S. Abdoulkader, A. Daher, J.F. Terral, S. Santoni, M. Ballardini, A. Mercuri, M. Ben Salah, K. Kadri, A. Othmani, C. Littardi, A. Salhi-Hannachi, J.C. Pintaud, and F. Aberlenc-Bertoss. 2015. Genetic structure of the date palm (Phoenix dactylifera) in the Old World reveals a strong differentiation between eastern and western populations. Ann Bot. (Lond.). 116:101-112. 